\title{
Fake News, (Mis) Information and Civil and Political Fundamental Rights
}

\author{
Janaina Rigo Santin ${ }^{1} \&$ Marlon Dai Pra ${ }^{2}$ \\ ${ }^{1}$ Passo Fundo University, Rio Grande do Sul, Brazil. PhD in Law from Universidade Federal do Paraná, Paraná, Brazil \\ ${ }^{2}$ Passo Fundo University, Rio Grande do Sul, Brazil. Master in Comunication from Universidade do Vale do Rio dos \\ Sinos, Rio Grande do Sul, Brazil
}

Correspondence: Janaina Rigo Santin, Rua Rio Branco n. 138, ap. 501, Vila Rodrigues, em Passo Fundo-RS, Brasil. CEP: 99070-080.

Received: December 29, 2020

Accepted: January 13, 2021

Online Published: February 26, 2021

doi:10.11114/ijlpa.v4i1.5115

URL: https://doi.org/10.11114/ijlpa.v4i1.5115

\begin{abstract}
This paper, built from a bibliographic review, using the hypothetical deductive method, deals with the growing problem related to the dissemination of false information, which in its turn interferes directly in the formation of public opinion and, consequently, in democracy and the fundamental civic rights exercise. Throughout the text, it is observed how this phenomenon is present and takes power in different media, particularly in electronic media, reaching many people and blurring the right to information. In this way the Brazilian political scenario was observed, especially in the 2018 electoral process, in which fake news marked the campaigns, bringing to the public a series of distorted values rather than cohesive proposals and well-defined strategies. From this analysis we understand the need for an education on the subject, so that the practices of disinformation can be gradually combated preserving and praising reliable information committed to the citizen's rights and democracy.
\end{abstract}

Keywords: information right, communication, public opinion, fake news, civic rights

\section{Introduction}

In face of the different sources of information that are present in everyday life, because of constant technological evolution, it is possible to see the production and distribution of different kind of information and content in an increasingly accelerated manner, which makes it increasingly difficult to identify sources and to filter the messages received through the most different media. The proliferation of fake news can be seen in different spheres, which goes from informal conversation in messaging applications and / or social networks to the mass media, that is, the news broadcasted by traditional vehicles such as radio and TV, which occasionally not only inform, but also form the public opinion, occupying positions of power that are sometimes unquestionable by the population.

It is important to highlight that the issue addressed here does not concern only the negative phenomenon that is observed using fake news, but above all, how the practice ruins the right to real and reliable information. By misrepresenting reality with "traces of truth", there is a distortion of entire collective imaginary and manipulation of public opinion, which, in its turn, leads to major problems in the most diverse aspects of social, political, and economic life.

The 1988' Brazilian Constitution establishes, in its Article 1, a "Democratic State of Law", thus radiating democratic values over the entire legal system and over all constitutive elements of the state. To respect the democratic value, the Brazilian State must be subject to popular sovereignty, freely clarified and informed. From this point of view, citizens must be recognized as persons integrated into a political society, with a connection between the concept of popular sovereignty (art. 1, $\S$ single), the exercise of political and civil rights (art. 5 and 14) and the concept of human dignity (art. 1, III). These elements will be combined with the right to education (art. 205), taking shape as an essential base and goal of the democratic regime. (Brazil, 1988)

In its turn, public opinion consists of nothing less than the source that gives legitimacy to the actions and power of State, causing the most diverse effects on the structure and functioning of the political body (Champagne, 1998:43). To the instituted power, this phenomenal instrument, which is the sharing of the decision on all legal regulations with the people, is not recognized with sympathy, given the historical difficulty of sharing the decision power with population. (Santin, 2017) It's so much better to use persuasion, often reached with false information provided, than simple state policy agreement. Thus, the public opinion becomes an element of vital importance to pressure the institutionalized space of 
public administration to take measures chosen and voted by all, establishing a popular will and the civic and politic fundamental rights as superior to the individual will of government. However, for this to occur, it is essential to have fair, honest, correct, ample, clear and, mainly, responsible information. Anything outside this context is precisely what we combat here: misinformation and manipulation.

The expression fake news has reached great notoriety in recent years and in 2018 had a very visible impact on the Brazilian political scene, when this practice changed the presidential election campaign in an evident way. Particularly regarding content that circulated freely through social networks, fake news reigned in an absolute way, due to the innovation in its use in the political process and in the despair of controlling bodies on its use. These factors make it possible to understand that the Internet is a lawless space, where absolutely everything can be shared. However, it is only this way of thinking that can legitimize such practices: by not paying attention to the subject, it becomes frighteningly liberated in everyone's life.

Thus, it is important to analyze the presence and effects of fake news in the political, social, and economic scenario, especially when we see this phenomenon from the perspective of the 2018 presidential events in Brazil. It is an increasingly evident theme in everyday life, and it should emphasize the fact that these practices are not limited to simply misinformation, but, above all, to harm or private the public from the right to access reliable information and even worse, making authentic information looks like lies by those who are the targets of fake news.

From this conception on the subject, some concepts will be approached to bring light on the theme and emphasize the importance of combating such practices with eyes on the future in which information is no longer treated merely as a product, but as some greater service, essential to a democratic society.

\section{Between Regulation and Emotion: The Falsification of Facts and Brazilian Law}

Towards the fast pace that present days gives to everyday life, it becomes more and more common that people with no time off, use digital tools to learn about different facts. Whether in search of information or entertainment, everything seems to be within reach of everyone in their smartphones, which works 24 hours a day. From the moment they wake up until bedtime a lot of content is consumed: news, amenities, funny videos, images, and even illegal content. This digitalization becomes progressively stronger, present and natural in daily life of ordinary people, so that it is difficult to think about what life would be like in a society without these resources which manifests itself in different spheres, according to Wilson Gomes, "Once ones admits that there is progressive digitalization of private life and social interactions, it seems an admitted natural consequence that there is increasing technological mediation of public life, which is life in society that has to do with public status or business, with the functioning regime of the political community and with its institutional form, the State". (2019: 1560)

This way of consuming different content more and more quickly gives people the illusion of being well informed about almost everything that happens worldwide. A fact that occurs in a distant country is instantly shown on social networks, on news channels and groups in messaging applications. Such facilities are particularly useful in everyday life and can help many people, playing an important role in democratizing knowledge and impressions of each person about many events. In the conception of André Lemos \& Pierre Levy (2010), access to information is democratized, previously held in the power of the mass media, where anyone can give their version of the facts, in different areas and at the same time. However, at the same time, in face of so many resources, the possibilities of spreading false information on a large scale are gradually increasing and reaching growing number of individuals, which can cause great losses. According to Antonio Pires \& Lilian Pires, "The modern world is exquisite in the available options, including in this context the speed of information technology which although it may constitute a new milestone of a participatory democracy, it may also be able to predict damages in countries and worse, lead public opinion to undesirable mistakes." (2018:102)

In this regard, attention falls on the ways in which fake news appears and proliferates reaching people of all nationalities, social classes, and education levels. And that does not mean that they are unaware or unable to interpret the information they receive, but that there are a large range of factors involved, in which the manipulation played by fake news can blind them in face of real events. Among these factors we must underline the emotional character in which the information is received by the audience which is spread in spectacular way that makes people identify themselves with what is shown and then believe in it, and in its turn sharing and disseminating such content. This is highlighted in Mathew D'Ancona (2018:38), for whom "what is new is the extension in which, in the new scenario of digitization and global interconnection, emotion is recovering its primacy and truth is retreating".

Following this logic, it is possible to observe the fact that fake news is often used by people to legitimize their own thoughts, which occurs when they see information compatible with their values and opinions and, without checking its veracity, shares it immediately, increasing the reach of fake news. Aside from the question of algorithms in force on social networks, which automatically select "equal" content for people who "think the same". That creates the false impression that "everyone thinks the same", presenting only one side of the truth, the one that is more convenient for that interlocutor. 
In this regard, it's important to emphasize the need for a careful analysis of information before disseminating it on the web. So, according to Mathew D'Ancona, "Rationality is threatened by emotion; diversity, by nativism; freedom by a movement towards autocracy". (2018:19) In other words, the values of each individual sometimes become more important than the facts themselves; people prefer what pleases and legitimizes their points of view and not what is grounded, what is real, and in this aspect, according to Eliane Brum, there is "an everyday life dominated by self-truth, a phenomenon that converts truth into a choice and therefore destroys the possibility of truth." (2019)

As it is very recent and worldwide issue, there is some difficulty in regulating fake news. The legal systems are national and do not present uniform treatment on the matter. Often there is no legislation in this regard in some countries. In addition, the difficulty in punishing virtual illicit behavior and acts, that in most cases, are desterritorialized, is huge.

It is a new phenomenon, made possible by another element of the present time, the digital platforms. These are new forms of communication that enable the widespread reproduction of false and distorted information that gain the appearance of reality. The negative consequences of the combination of fake news and digital platforms are incalculable, as public debate is distorted, corrupting freedom of expression and the right to information, two of the main assets of democracy in relation to other political regimes. In electoral contexts, the impact of misinformation tends to be even more harmful. Thus, it is not overstatement to say that fake news is a threat to democracy itself, as it can distort electoral results. Electoral abuses cannot be admitted interfering with the supremacy of the ballot box. It is crucial to create effective mechanisms to prevent the spread of fake news during elections. (Queiroz, 2019:11)

Brazilian electoral legislation, even though it provides penalizing for misinformation or fake news at election times, was unable to reject these practices, which occurred forcefully in the presidential elections of 2018. Since the 1950's Electoral Code, there already was a prediction in its article 175 , subsection 28 , that it would be a crime "to refer in propaganda untrue or insulting facts in relation to parties or candidates and with the possibility of exercising influence before the electorate". (Brazil, 1950) This regulation was repeated after the civil-military coup of 1964, with the Law of 1965, in its article 323, which established as an electoral crime "to publicize, in propaganda, facts that you know are untrue, in relation to parties and candidates and capable of perform influence on the electorate". (Brazil, 1965) In the words of Henrique Neves.

This writing [of the article] is a little complicated because it assumes that the person who is publicizing knows that it is untrue, that is, the deceit has to be specific, and then here it would approximate more or less those concepts of American law, so discussed in the [case] of New York Times versus Sullivan, in which the crime would only be characterized when there was real malice or else the reckless disregard of the person who is broadcasting the news is sure that the news is false. [...] Regarding the elections themselves, Law No. 9.504 / 1997 also deals with falsehoods in art. 58, by guaranteeing the right of reply from the moment of choosing candidates in convention, it is possible for the candidate, party or alliance that are offended, affected, to seek the right of reply before Electoral Justice. Precisely, the party, the alliance or the candidate who are affected, "even if indirectly, by concept, image or slanderous, defamatory, insulting or known as untrue'. (Neves, 2019:40)

Thus, in 1965, the Brazilian electoral law already provided this right of reply, but there was no possibility that the alliance or the party would be responsible in cases which they came to claim that they did not produce the information conveyed (in view of the need for proof the of specific deceit). This situation was changed recently, on December 18, 2019, when the Superior Electoral Court (Tribunal Superior Eleitoral - TSE) approved a resolution trying to reduce the use of fake news during the 2020 municipal elections. The new rules oblige candidates, parties, and alliances the responsibility to check the veracity of any information transmitted in their campaigns before spreading it through electioneering - even those produced by third parties. If the disclosure of false information is verified, the offended candidate may have access to the right to reply, without prejudice by any criminal liability. Therefore, with this recent resolution, the objective is to avoid, in a more striking way, the propagation of misinformation in elections by the candidates, making it possible to be held accountable even without proof of fraud, but rather through negligence that is due to the lack of care by the party, alliance or candidate to check the veracity of the information it disseminates in its electoral campaign.

Regarding the hiring of people or groups for the dissemination of untrue news on the internet, the 1997's Electoral Code (updated by Law 12.891/2013), in its article 57-H, $\S 1$, defined as a crime, to be punished with "detention from 2 (two) to 4 (four) years and from R $\$ 15,000.00$ (fifteen thousand reais) to R $\$ 50,000.00$ (fifty thousand reais) fine", (Brazil, 1997 ) without prejudice to the other legal applicable sanctions to "direct contracting or group of people with the specific purpose of sending messages or comments on the internet to offend honor or to denigrate the image of a candidate, party or alliance". (Brazil, 1997) And in its 2nd paragraph it stated that it will also incur crime, "punishable by detention from 6 (six) months to 1 (one) year, with the alternative to provide services to the community for the same period, and from $\mathrm{R} \$ 5,000.00$ (five thousand reais) to $\mathrm{R} \$ 30,000.00$ (thirty thousand reais) fine" (Brazil, 1997) to the people who were hired to disseminate such news. 
Finally, it is important to underline article 57-I of the Brazilian Electoral Code (amended by Law 13.488/2017), when it provides that Electoral Justice, on request of the resentful party, may determine the suspension of up to 24 hours of access to all content conveyed by the party, the alliance or the candidate who violates the provisions of the electoral law. If the conduct is repeated, the suspension period is doubled and the company must inform all "users who try to access its services, that it is temporarily inoperative due to disobedience to the electoral legislation." (Brazil, 1997)

It can be seen, therefore, that in Brazil, even with large regulation aimed at preventing fake news and its spread by groups hired for this purpose, this proved to be insufficient and of a small practical application, according to the electoral format used in 2018, in which the speed of dissemination of misinformation through social networks prevailed. Certainly, this factor, when decisive in an election, fatally undermines the credibility of the legal and political institutions of the country, undermining the smoothness of the democratic procedure as a whole thing.

Dealing with the aspects of contemporary electoral scenario experienced not only in Brazil but also in the United States and other Western countries, Brian McNair defines this century as a period in which uncertainty hangs over the veracity of what is conveyed. (McNair, 2017:38) Fake news predominates on the scene, as well as "intentional misinformation (invention or falsification of known facts) for political and/or commercial purposes, presented as real news." (McNair, 2017:38). Brian McNair brings to light the malicious bias of this practice, which treats information as a medium of deceiving and targeting someone, as a product sold to harm public opinion and, consequently, democracy.

\section{Public Opinion, Power and Legitimacy}

It is known that legitimacy has a preponderant role in law and politics, as it stems from a rational acceptance on the part of individuals, arising from the union between opinion and will, and translates into the incorporation of the exercise of citizens' political autonomy in State. (Habermas, 2003a:172) Popular participation can take place in several ways, together or apart: political parties, popular councils, plebiscites, referendums, the popular initiative for creating laws, popular consultations, public hearings, among others. However, popular engagement comes from a healthy exercise of participation in which the communication assumptions and processes capable of resulting in the union of individual freedoms with collective actors and state institutions must be present. While the gathering of citizens who can be individualized from the whole picture takes place, the same group finds itself an unnamed and abstract mass, capable of actions that can shake the most solid perceptions and bases of a government.

Jürgen Habermas notes that, when people unite around a subject to be addressed, it is possible to verify the existence of several conflicting arguments, resulting from different ideological currents and according to the individual orientation of each public space, and tend to lead to general understanding in the public sphere. (Santin \& Hamel, 2014) The different public spaces act in a way to seek unanimity, as a rule, guided by the values resulting from common sense. On the other hand, the actors that make up the public spaces can act under the guidance of their own interests, aspiring something they want to defend or a commitment to be signed with another part. (Santin \& Hamel, 2011)

Now they use their forces for a cause, citizens who make up the different public spaces denote that they are going to find solutions through the formalization of a collective and public will. Without a doubt, the social power that this mass represents is based on a set of norms, to combine human dignity, customs, ideology, politics, values and moral in addition to the law itself. And this comprehension or negotiation occurs with a well-defined structure, with contributions, information and arguments, logically supporting rationality to achieve the results desired by the majority. (Habermas, 2003a:178) In the plural clashes that occur in the public sphere between the different public spaces, the millennial attitude of the predominance of the best argument between speaker and listener prevails. Valid convictions are produced or reinforced, free from coercion and participation, capable of referring to the rational and democratic acceptance of relevant rights or duties, aiming at the creation of new social realities through communicative freedoms (Habermas, 2003a). To know:

[...] political power is not a potential for the imposition of self-interests or the achievement of collective purposes, nor some administrative power capable of making mandatory decisions collectively; it is, instead, an authorizing force that manifests itself in the creation of rightful law and in the foundation of institutions. It manifests itself in orders that protect political freedom, in opposition to the repressions that threaten the whole political freedom, especially in the acts that institutes freedom. (Habermas, 2003a:187)

It is important to emphasize that when discussing collectively the demands, there should be equal chances and freedoms, as well as clear and free from manipulation information. However, it is known that groups with greater economic potential tend to stand out somehow over the others, often using their influence to achieve their goals or as demonstrated more recently, with the use of fake news. These are called "interest groups".

Trying to interpret the people's judgment is one of the most complicated tasks. It is imperative that the communicative assumptions are fulfilled through the hearing of all interested parties, free from coercion and on equality in the 
presentation of their arguments, once being external to the democratic decision-making procedure, the situations involved and the interests in stake will never be fully revealed. This enforces the interested party to situate itself in the whole subject, penetrating the dialogues' core and observing particularly the different (dis)information, arguments and opinions of the actors involved, and only then have a reasonable understanding of the "game" in progress. On the other hand, such immersion does not mean that the totality will be completely known, since the movements are often made in the dark and even before the very beginning of the dialogues.

The majority rule, in the case of group decisions, is like the search for fairness and truth, establishing itself as an essential aspect in the legal regulation of collective deliberation processes. From this occasion, the decision of the totality demands the due treatment of the covered objects, and that all the legal and moral rules of all involved were respected. (Habermas, 2003a:223) In other words, the political formation of public opinion must clarify three latent doubts: the formation of commitments, since without this objective, a meeting of people with political intent would be a waste of time; the ethicalpolitical issue, which deals with the different ideological currents supported by each group; and, finally, the practicalmoral question, which refers to the thought and action of the whole, for the whole. If such issues are addressed in the process, it will therefore be configured in an aggregate and authentic general will. (Habermas, 2003a:225)

From a social point of view, it would be great, spite of being impossible, to analyze how everyone's own hermeneutics, as well as each group or space that makes up the public sphere, about the information and misinformation (fake news) that successively go appearing in the debates. For that, a research with complete and accurate data of all involved parts should be carried out in advance, simultaneously with the political game being played, a more accurate reading of the logical reasoning leading to one or another action or decision was obtained. (Habermas, 2003b:32)

In Jürgen Habermas' words, the public sphere constitutes a relevant communicational structure for the smooth progress of processes, since the "modus operandi" is the individual and collective action guided by and for mutual understanding. It becomes a network dedicated to the communication of contents, opinion and decision making, where the communication flows are filtered and synthesized in public opinion. For the totality of the topics addressed during the exchange of ideas for which reasons for or against are alleged, with a view to a conclusion to be effective, it is fundamentally important to completely relegate technical language, as well as codes that are not largely dominated by those involved. Only in this way will the uneducated orientation be able to achieve the abstraction necessary to discern the shared opinions, as well as the concrete obligations of each part included in the dialogue. Actors should be forced to achieve the intellectualization of themes through simpler and less complex means, such as, for example, natural language at the expense of symbolic language. (Habermas, 2003b:93)

However, it is not uncommon to see that public opinion is an open door for malicious political influences, which aim to interfere in the electoral behavior of people with the spread of fake news to interfere in independent formation unaffected by the will. Certainly, today's media have a wide range of tools that can identify such behaviors, to restrain them and punish those responsible for the spread of fake news. Nevertheless, it is necessary to point up that the procedures of surveillance would be useless without the political subject - in this case both people and institutions - did not have the interest, skills, and critical knowledge to check the information that spread out on the web to make their judgments and decisions as close as possible to reality and their interests and values.

Although the power of fake news is clear to everyone, especially in electoral times, it is almost impossible to have such sharpness in the way that social networks with their message flows and the mass media influence and even manipulate public opinion formed in the public sphere. The only certainty left is that there is some pressure that, at the same time, can change the course of state actions and decisions.

Michael Gurevitch and Jay G. Blumler highlighted the media process in constitutional political systems through the following points:

- To watch over the socio-political environment, bringing to the public the developments capable of interfering, positively and negatively, in the citizens' welfare;

- To define the significant issues on the political agenda, identifying the key elements, as well as the forces that originated them and can lead to a solution;

- To establish platforms that allow politicians, agents from other causes and other interest groups, to defend their positions in an accessible and enlightening way;

- To allow the dialogue between different points of view and between powerholders (current and future) and the mass public;

- To create mechanisms that enable those responsible to be inform how their power is performed;

- To encourage citizens to learn, choose and get involved in the political process, refusing their role as mere spectators; 
- To resist, on behalf of well-defined principles, efforts outside the media that attempt to subvert their independence, their integrity and their ability to help the public;

- To respect members of the audience and reader as virtual involved and able to understand their political environment. (Gurevitch; Blumer apud Habermas, 2003b:112)

According to these points, social networks, and the mass media, when exercised to inform and defend the citizens' interests on the political society, the viewers can be encouraged to learn and criticize, and even more, to analyze nondiscriminatory the public's concerns and suggestions, intending to pressure the political process to take the necessary decisions towards legitimizing subjects of public interest. In that way, the media power can neutralize and block the administrative power to perpetuate the economic and cultural gap between the various strata of society using political-advertising influences. (Habermas, 2003b:112) However, this is not always the case, because often the interest groups that own the mass media are not concerned with the collective interest, but with their own interests, which represent a great risk to democratic management facing the capacity for manipulation. of public opinion performed using fake news.

Therefore, there should be hope for greater seriousness with the dissemination of information, so that the concerns developed here support the critical orientation of public opinion, to spread the population interest in this issue, which deserves greater space on the public agenda, to allow sufficient pressure to include the fake news story on the political agenda, so that it can be treated widely and seriously. However, it is important to emphasize that even using the democratic method of formation of legal-political guardianship, interest groups that manipulate public opinion and use the spread of fake news through media channels are often able to insert their demands on the formal agenda of the public sphere, as though the demand corresponded to the pretensions of the population, taking a different direction from the interests objectified by most of the population. (Habermas, 2003b:114)

\section{4. (Mis)Information as a Product}

When treating information as simple products, work and the effort of journalists who work with ethics are disqualified, who take risks based on what they believe in, who base their activity on values of great importance and are committed to inform the public about different facts, so that, based on what is being shown, has their own conclusions, without being forced to believe in a fabricated reality. In this regard, it is important to note that as the news aims to expand the range of a particular channel or attract likes and new followers for its sharing platform, among other activities, there is some distance from the purpose and commitment to inform. In this sense, from the perspective of Esteban Illades, "The news is treated like product and not as information. That is why some media produce today is called content, 'content', and not news. Because it is a product for a customer who wants to receive something digestible and fast and wants it without much effort." (2018:2201)

It is worth reinforcing the questioning about what is consumed, shared, and not investigated. Certainly, what would be required of a critical and culturally advanced society is that the news transmitted by both the mass media and by uncertain sources should be interpreted, analyzed with sufficient time to check its sources. However, the speed required in contemporary events does not allow this depth, it is possible to notice that the spread of fake news in general occurs through some patterns. Initially a kind of "decoy" is created, which has the objective of attracting the public's attention, either through an instigating title (usually appealing and/or sensationalist) or a shocking image or, even more clearly, the combination of these two elements. The second step is to take the graphic characteristics of renowned vehicles, creating a visual that resembles what the public usually sees as a reliable and widely circulated medium. Afterwards this content becomes a major disadvantage to the community by distorting facts and opinions to cheat the public through a lot of misinformation as analyzed by Juliana Gragnani (2018), who during the 2018 election campaigns verified 272 political groups, from different ideologies and political parties on WhatsApp.

On the opposite side of fake news, it is important to consider that there are great agents fighting against this harmful practice and "it is possible to realize that journalism has a strong role in social education. In addition to bringing news and reports to the public, journalism is crucial for the formation of public opinion". (Paiero; Santoro; Santos, 2018:52)

Serious and ethical journalism serves to inform and make better and more enlightened society, working for democracy. Behind the fake news there are usually no ethical, serious, and competent journalists, nor people with the commitment to bring the population the truth about their time. On the other hand, there are people - and organizations - with the intention of obtaining some gain, whatever it is financial, political, economic, cultural, or ideological, which, in any case, represents a great loss to democracy.

\section{Democracy's Fight Against Fake News and the Right to Information}

On face of the strong presence of fake news in electoral periods, it is difficult for the public to filter, refine and select what they receive. Article 220 of the Brazilian Federal Constitution of 1988 provides guarantees for freedom of expression of thought, creation, expression, and information. However, such freedoms presume the good faith of the means that work 
with access to information and communication. In order to combat those ones who abuse this freedom and create fake news, it is imperative to have conscientious citizens with some high cultural and educational standard, capable of developing a critical sense of what is presented to them. They need to value their rights and fight to preserve them, and avoid going against the constitutionally guaranteed democratic principles, so important for society in general. Consequently, according to Carlos Souza \& Chiara de Teffé, "Disinformation undermines confidence in traditional and digital institutions and media, as well as compromising the sane development of democracies." (2018:178)

Norberto Bobbio's view on the principle of advertising and the right to information as fundamental to the exercise of the democratic ideal is remarkable, which finds in the Kantian discourse the justification of the democratic ideal and states that Kant was the first philosopher to reflect on advertising in power to rescue man from his "state of minority". To overcome such a state, it would be necessary for the power to have no more secrets, to act in public, so that, from publicity, the man gifted with reason will have full knowledge of state actions. It is indispensable, thus, to condemn confidential government acts and institute publicity and accountability of its decisions to citizens. (2002:405-409)

However, Norberto Bobbio denounces the difficulty of obtaining the transparency of power, pointing that "among the promises not kept by democracy [...] the most serious, and the most destructive, and, apparently, also the most irremediable, is precisely the transparency of power". (2002:409) This non-fulfilment occurs due to the irresistible tendency of the powerholder to keep his acts confidential, turning the secret to be an instrument of power, which was evidenced from the development of Weberian bureaucratic power, present even in democratic states, as seen in the conduct of US foreign policy. (2002:409-414)

It is known that it is impossible to control some hidden power, that keeps its acts secret. Democracy is the government regime that provides maximum control of individuals over power; however, "this control is only possible if the public authorities act with maximum transparency. It is part, in short of the very logic of democracy". (Bobbio, 2002:414) In the same sense is the reflection of Pierre Rosanvallón, remembering that the democratic ideal is strengthened by conflicts, making them productive and constructive. Never by denying or hiding them to obtain an "unlikely consensus". In the author's view, the development of democracy and increasing the visibility of power before society goes side by side. (1997:95-96) In this way, the principle of transparency is the enabling instrument both for state controls in public administration and for social control, with a view to solve the "black box" of public management for the inspection of social bodies and citizenship. Based on the full public knowledge of information and publicity and transparency of administrative acts, it will be easier to verify compliance by government with the constitutional principles of the legaladministrative regime, especially participation, impersonality, morality and efficiency by the control agents, along with the fulfillment of social rights, in an interaction between the government and civil society (Mileski, 2002). It's "from transparency, therefore, that social control will emerge as an imperative order of a constitutional character, "participating in the more or less universalized effort to democratize power, making it visible and, as it were, more reliable and limited in its temptations of arbitrary or conformist omission"”. (Freitas, 2001:15)

The facilities coming to light from the use of available technological resources and new information and communication technologies, as well as the plurality of sources to be consulted (and contested), must be tools for expanding the individual's ability to achieve democratic values, and not the opposite, as limits to their power. Social relations based on the multiplicity of ideas mean that there is space for everyone and that, together, it will be possible to collaborate for greater social, political, cultural and economic development.

It is essential to know how to differ what benefits the population and what harms the whole society, and thus prepare for today's challenges. According to Diogo Rais, "The connection between politics, elections and technology tends to advance more and more, requiring from all actors not only the preparation to deal with new challenges, but also the capacity for self-transformation to face technological changes and innovations, regardless its best effects or its side effects." (2018:105)

It is necessary, therefore, that the public leave behind the comfortable position of being a mere spectator of what is automatically provided by the various media, traditional and contemporary ones, to act critically on the information that comes to their knowledge. In the same way that fake news is strongly present, there are also ways to investigate them. From the moment a fact comes to light, it is essential to check its sources. The search for different information channels and reliable communication tools, against the acceptance of content with no credibility is one of the ways to combat fake news. This critical position about the published content should be encouraged so that gradually the public becomes more perspicacious and does not let itself be influenced by fabricated truths that seek essentially to harm them, to violate their fundamental rights and to manipulate and their opinion and freedom of thought.

Taking a critical look about this theme, it is important to consider the length of certain guidelines and the reason why they are in circulation, and not simply accept them as truths. In this respect, the role of the State as a regulator becomes indispensable, in the creation of mechanisms capable of combating this type of activity in the most different forms, among which is the need to instruct the public to develop a more sensible and wise view about the content they consume. 
According to Irene Nohara, "State measures must be reflected in the sense of preserving the core of freedom of information, and it is important to maintain network neutrality, as a condition for the free and unpaid dissemination of information, and that State encourages the existence of public policies of promotion of digital education. (2018:87)

Thus, it is worth highlighting the role of education in the formation of more critical citizens, prepared for the challenges of the present, so that this type of problem can be significantly reduced in the future.

\section{Final Remarks}

Throughout this review, combating fake news is not a simple task. It is necessary to unite public, State, media, in addition to understanding and full education of citizens, so that their emotions, interests and particular values cannot be deceived. The use of fake news, especially in the electoral period, directly affects the effectiveness of fundamental political or civic rights since they manipulate public opinion and misinform the citizen.

In this context, the point here is to ask how good, for the powerholders, an audience capable of discern between what is true and what is false between facts and media creations, is. After all, if during recent electoral campaigns, the use of fake news has proved to be an important tool to convince (manipulate) the electorate and win the elections, it is possible to see that, after the victory, the tendency is that such devices continue to be used to distort and omit facts.

The interests of someone or some group cannot be placed above democratic values and must be treated more seriously to restrain the contamination of public opinion through dishonest, unfair, and unconstitutional practices that aim, above all, to harm the fundamental right to information.

\section{References}

Bobbio, N. (2002). Teoria geral da política: a filosofia política e as lições dos clássicos. Rio de Janeiro, RJ: Campus.

Brazil. (1950). Lei $n^{o}$ 1.164, de 24 de julho de 1950. Institui o Código Eleitoral. Retrieved from http://www.planalto.gov.br/ccivil_03/leis/1950-1969/L1164.htm

Brazil. (1965). Lei $n^{o}$ 4.737, de 15 de julho de 1965. Institui o Código Eleitoral. http://www.planalto.gov.br/ccivil_03/leis/L4737.htm.

Brazil. (1988). Constituição Federal de 1988. http://www.planalto.gov.br/ccivil_03/Constituicao/Constituicao.htm.

Brazil. (1997). Lei $n^{\circ}$ 9.504, de 30 de setembro de 1997. Estabelece normas para as eleições. Retrieved from http://www.planalto.gov.br/ccivil_03/leis/19504.htm

Brum, E. (2019) Doente de Brasil: como resistir ao adoecimento num país (des)controlado pelo perverso da autoverdade. El País, Madrid, 02-08-2019, Retrieved from https://brasil.elpais.com/brasil/2019/08/01/opinion/1564661044_448590.html

Champagne, P. (1998). Formar a opinião. Petrópolis, RJ: Vozes.

D’Ancona, M. (2018). Pós-verdade. Barueri, SP: Faro Editorial.

Freitas, J. (2001). O controle social do orçamento público. Revista Interesse Público, 11(3),13-26.

Gomes, W. (2019). A democracia no mundo digital: história, problemas e temas. São Paulo, SP: Ed. SESC.

Gragnani, J. (2018). Um Brasil dividido e movido a notícias falsas: uma semana dentro de 272 grupos políticos no WhatsApp. BBC News Brasil, São Paulo, 05-10-2018, Retrieved from https://www.bbc.com/portuguese/brasil45666742

Habermas, J. (2003a). Direito e democracia: entre a facticidade e validade. (Vol. 1), (2nd ed.). Rio de Janeiro, RJ: Tempo Brasileiro.

Habermas, J. (2003b). Direito e democracia: entre a facticidade e validade. (Vol. 2), (2nd ed.). Rio de Janeiro, RJ: Tempo Brasileiro.

Illades, E. (2018). Fake news: la nueva realidad. México, DF: Grijalbo.

Lemos, A., \& Levy, P. (2010). O futuro da internet: em direção a uma ciberdemocracia planetária. São Paulo, SP: Paulus.

Mcnair, B. (2017). Fake news: falsehood, fabrication and fantasy in journalism. London, England: Routledge. Retrieved from https://doi.org/10.4324/9781315142036

Mileski, H. S. (2002). Transparência do poder público e sua fiscalização. Revista Interesse Público, 4, 24-36.

Neves, H. (2019). Lei eleitoral e os limites da propaganda. In Anais Seminário Internacional Fake News e Eleições, (pp. 32-55). Brasília, DF: Tribunal Superior Eleitoral. Retrieved from http://www.justicaeleitoral.jus.br/desinformacao/arquivos/livro-fake\%20news-miolo-web.pdf 
Nohara, I. P. (2018). Desafios da ciberdemocracia diante do fenômeno das fake news: regulação estatal em face dos perigos da desinformação. In D. Rais (Org.). Fake news: a conexão entre a desinformação e o direito, 75-88. São Paulo, SP: Thomson Reuters Brasil.

Paiero, D. C., Santoro, A. C. T., \& Santos, R. F. (2018). As fake news e os paradigmas do relato jornalístico. In D. Rais (Org.). Fake news: a conexão entre a desinformação e o direito, 51-59. São Paulo, SP: Thomson Reuters Brasil.

Pires, A. C. M., \& Pires, L. R. G. M. (2018). Desinformação: atuação do Estado, da sociedade civil organizada e dos usuários da internet. In D. Rais (Org.), Fake news: a conexão entre a desinformação e o direito, 89-104. São Paulo, SP: Thomson Reuters Brasil.

Queiroz, L. V. (2019). Manifestação dos componentes da mesa de abertura. In Anais Seminário Internacional Fake News e Eleições. Brasília, DF: Tribunal Superior Eleitoral. Retrieved from http://www.justicaeleitoral.jus.br/desinformacao/arquivos/livro-fake\%20news-miolo-web.pdf

Rais, D. (2018). Fake news e eleições. In D. Rais (Org.), Fake news: a conexão entre a desinformação e o direito, 105129. São Paulo, SP: Thomson Reuters Brasil.

Rosanvallón, P. (1997). A crise do estado-providência. Brasília, DF: Editora da UnB.

Santin, J. R. (2017). Estado, Constituição e administração pública no Século XXI: novos desafios da cidadania e do poder local. Belo Horizonte, MG: Arraes.

Santin, J. R., \& Hamel, M. (2011) Relações sociais e sociedades pós-convencionais: reconfiguração do espaço público e redimensão do poder jurídico-político. Revista Justiça do Direito, 25(2), 11-27. Retrieved from https://doi.org/10.5335/rjd.v25i2.4000 Ed. Especial.

Santin, J. R., \& Hamel, M. (2014). O princípio da participação e o novo protagonismo da sociedade civil no Brasil: por uma nova teoria da emancipação social. Direitos Culturais, 17(8), 109-127. Retrieved from http://dx.doi.org/10.20912/rdc.v9i17.1027

Souza, C. A., \& Teffé, C. S. (2018). Fake news e eleições: identificando e combatendo a desordem informacional. In G. Abbpid \& N. Nery Júnior (Orgs.). Fake news e regulação, 177-189. São Paulo, SP: Thomson Reuters Brasil.

\section{Copyrights}

Copyright for this article is retained by the author(s), with first publication rights granted to the journal.

This is an open-access article distributed under the terms and conditions of the Creative Commons Attribution license which permits unrestricted use, distribution, and reproduction in any medium, provided the original work is properly cited. 